\title{
Understanding Political Corruption in Low Income Countries
}

Rohini Pande

\author{
CID Working Paper No. 145 \\ April 2007
}

(C) Copyright 2007 Rohini Pande and

the President and Fellows of Harvard College

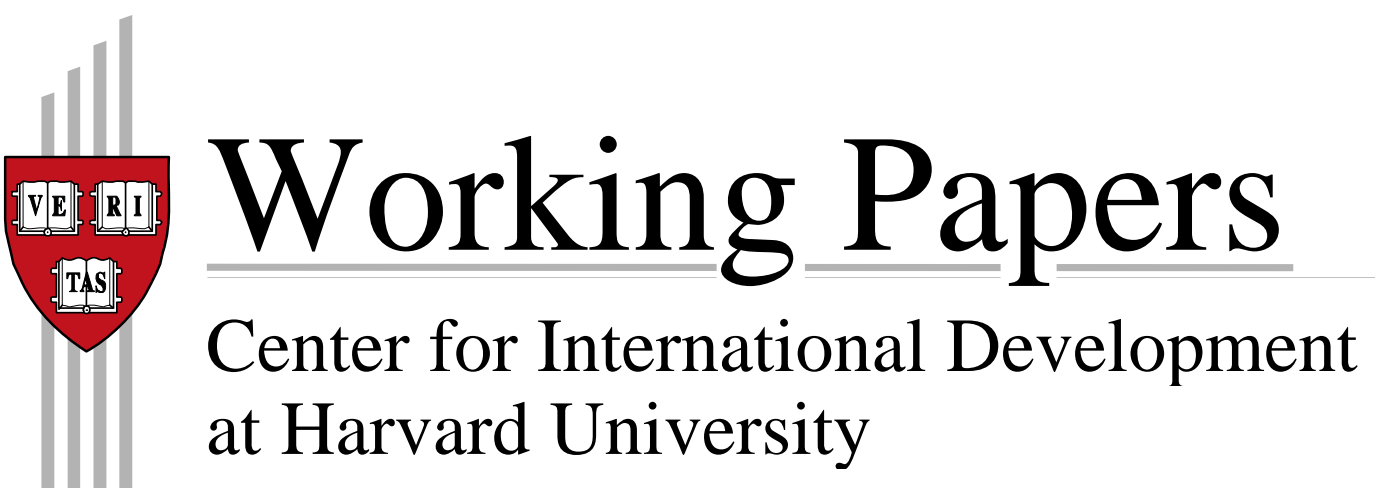




\title{
Understanding Political Corruption in Low Income Countries
}

\author{
Rohini Pande * \\ Harvard University \\ April 15, 2007 \\ Chapter for the Handbook of Development Economics, Volume 4
}

\begin{abstract}
Building on the large and growing empirical literature on the political behavior of individuals in low income countries this chapter seeks to understand corruption through the lens of political economy - particularly in terms of the political and economic differences between rich and poor countries. Our focus is on the political behavior of individuals exposed to democratic political institutions and its implications for corruption. We review the existing literature on the determinants of individual political behavior to ask whether we can understand the choice of political actors to be corrupt and, importantly, of other individuals to permit it, as a rational response to the social or the economic environment they inhabit. We also discuss the implications of this view of corruption for anti-corruption policies.
\end{abstract}

${ }^{*}$ Thanks to Daniel Fetter for excellent research assistance and Abhijit Banerjee, Marcel Fafchamps, Asim Khwaja and, especially, Dominic Leggett for discussion. 


\section{Contents}

1 Introduction $\quad 3$

2 Politician Identity and Political Corruption $\quad 6$

3 The Political Organization of Low Income countries and its Conse$\begin{array}{ll}\text { quences for Corruption } & 10\end{array}$

3.1 The Economic Environment and Politics . . . . . . . . . . . . . . . . 10

3.2 Implications for opportunities for corruption . . . . . . . . . . . . . . . 15

3.2.1 Power and Networks . . . . . . . . . . . . . . . . . . . . . 15

3.2.2 Ethnicity and Gender . . . . . . . . . . . . . . . . 16

3.2.3 Public Allocation of Resources and Regulation . . . . . . . . . . . . 17

3.2 .4 Information . . . . . . . . . . . . . . . . 20

3.3 Implications for willingness to tolerate corruption . . . . . . . . . . . . 21

3.3.1 Redistributive Preferences . . . . . . . . . . . . . . . . . . 21

3.3 .2 Participation . . . . . . . . . . . . . . . 25

3.3.3 Monitoring . . . . . . . . . . . . . . . . . . . . 32

4 Conclusion $\quad 33$ 


\section{Introduction}

A growing body of evidence suggests that corruption in low income countries is a significant constraint on economic performance (see, for instance, Mauro (1995) and Treisman (2000)). ${ }^{1}$ The most common definition of corruption in the economics literature is the misuse of public office for private gain. While private gain is typically interpreted in terms of monetary benefit, it can potentially include non-monetary benefits such as improved chances of reelection and helping friends or members of their social or ethnic networks obtain public resources. The usual interpretation of misuse is the use of office for illegal purposes, but it is occasionally construed more broadly as the mis-allocation of public resources in ways that enhance the official's private returns.

Recent years have also seen an explosion of empirical research on corruption measurement. This research, which has developed and used both subjective indices which are based on perceptions of corruption and objective measures of either illegal activity by politicians or the extent of theft of public resources ${ }^{2}$, typically finds a relatively high incidence of corruption in low income countries (Svensson 2005).

A common explanation for this observation is that corruption is a social norm/habit that is much more pervasive in low income countries. That is, on average citizens in low income countries are relatively more willing to condone corruption and less likely to want to use their electoral power to vote out the corrupt. The presumption is that this has, in turn, reduced economic growth in these countries. Fisman and Miguel (2006) use data on diplomatic parking ticket violations in New York city to suggest that highly corrupt countries are, on average, countries with a widespread acceptance of corrupt practices. They exploit the fact that diplomatic immunity in New York city meant essentially zero

\footnotetext{
${ }^{1}$ Mauro (1995) estimates a one standard deviation reduction in corruption would raise investment rates by almost 5 percentage points, and annual GDP growth by half a percentage point. Some of the likely channels of influence include (i) corruption, by acting as an additional tax, may lower individual work incentives, and (ii) rent seeking which leads to a mis-allocation of labor.

${ }^{2}$ The most well-known and widely-used indices from Transparency International and the World Bank mix both types, but are dominated by expert surveys.
} 
legal enforcement of diplomatic parking violations to show that the incidence of parking violations by diplomats from a country is strongly positively correlated with other country corruption measures. This relationship is robust to conditioning on region fixed effects, country income, and a wide range of other controls (including government employee salary measures). In a similar vein, Barr and Serra (2006), in an experiment at Oxford University, show that a participant's willingness to offer bribes in a laboratory setting is correlated with the corruption record in his/her home country. Both papers interpret their findings as suggesting that that social norms are important in explaining the incidence of corruption. This would suggest that corruption would require a change in ideology rather than a change in institutions or economic conditions. ${ }^{3}$

The notion that a high incidence of corruption in a society reflects, in part, social acceptance of corrupt practices (and individuals) has been influential in policy circles. The US government and the World Bank, for instance, are strong proponents of the view that support for development aid should be made conditional on the extent to which a country succeeds in reducing corruption. ${ }^{4}$ This view would seem to assume that a country's ability to reduce corruption is independent of its economic status (Pande 2006).

This view stands in contrast to the idea that corrupt behavior is a choice made by specific individuals who make or implement policies and is at least partly a rational response to the structure of the political or economic environment. In this environment citizens' choice to vote for the corrupt may reflect the economic constraints they face rather than a willingness to condone corruption. In this chapter we develop this approach. Building on the large and growing empirical literature on the political behavior of individuals in low

\footnotetext{
${ }^{3}$ However, the findings of both papers remains consistent with an alternative explanation. That is, corruption in a low income country may be caused by a small set of opportunistic individuals who are able to succeed in the existing politico-economic system and are also the ones able to get coveted diplomatic jobs in New York and/or send their family members to prestigious universities abroad.

${ }^{4}$ Since 2005 concerns of corruption have caused the World Bank to delay a 800 million dollar loan for health related services to India, cut debt relief to the Republic of Congo Brazzaville, suspend 261 million dollars of aid to Kenya and withhold 124 million dollars of disbursement to Chad.
} 
income countries we try to understand corruption through the lens of political economy particularly in terms of the political and economic differences between rich and poor countries. Individual political behavior and political outcomes in any society are constrained by its political institutions (Persson and Tabellini 2003). ${ }^{5}$ Political institutions provide the structure for collective decision-making, and define the context for resource redistribution and public good provision by governments. An important potential constraint on corruption is the democratic political process which gives voters the opportunity to dismiss corrupt politicians and to support laws that constrain corruption.

Our focus is on the political behavior of individuals exposed to democratic political institutions and its implications for corruption. We review the existing literature on the determinants of individual political behavior to ask whether we can understand the choice of political actors to be corrupt and, importantly, of other individuals to permit it, as a rational response to the social or the economic environment they inhabit.

We argue that many factors that affect the extent of corruption vary with economic development. These include the personal motivation of those who enter politics and their subsequent remuneration, the opportunities for corruption, the relative strength of institutions to identify and prevent corruption, the extent to which bureaucrats are accountable to elected officials, and how individuals trade-off politician quality against the policies and transfers associated with different politicians. For instance, a higher incidence of poverty in a country, combined with imperfect credit markets, may create popular pressure to allocate resources through the political process. If this, in turn, is accompanied by increased regulation of the allocation process then opportunities for corruption may increase. In addition, if voters have preferences over both politician honesty and his/her ability to target resources towards their group then increased resource allocation through the political process may reduce the extent to which the electoral

\footnotetext{
${ }^{5}$ In this chapter we do not examine the direct implications of institutional form for political corruption (for a more general discussion of how institutional form affects policy outcomes see, for instance, Acemoglu, Johnson, and Robinson (2005) and Pande and Udry (2005)).
} 
process constrains corruption.

In section 2 we describe the relevant political economy literature, and identify the likely links between the political process and politician corruption. In section 3 we identify how the economic organization of low income countries may affect the allocation of political power, and its implications for the incidence of corruption. In section 4 concludes.

\section{Politician Identity and Political Corruption}

In what ways can an individual in a position of political power exploit that position to further his private ends, and what constrains his actions?

First, he may steal resources, either by directly plundering public coffers or by exploiting his position as a regulator of economic activities and taking bribes (Gehlbach and Sonin 2004) . The classic example of this is the use of red tape, i.e. complex rules and regulations associated with transferring resources to particular individuals that gives the political actor a pretext to extract bribes (Banerjee 1997). While the literature has typically focussed on bureaucratic red tape, evidence suggests that in many countries politicians deal directly with situations involving red tape.

Second, a politician may engage in corruption of the electoral process by vote buying or, more indirectly, by exploiting her control over the media and limiting the information available to citizens. For instance, Besley and Prat (2006) use data from 90 countries in 1999 to show that corruption is positively correlated with political longevity, and press freedom is negatively correlated with political longevity. Further, the share of state ownership of newspapers is positively correlated with corruption, negatively correlated with print freedom and positively correlated with political longevity.

Finally, a politician may misallocate public resources by, for instance, choosing to target resources towards specific groups of citizens, such as her own ethnic group. Whether such pork barrel politics constitutes illegal practice varies across countries and contexts.

How does the political process potentially constrain opportunistic behavior by elected 
officials?

The most immediate answer, and the one explicitly related to the political system, is by voting the corrupt out of office. Ferraz and Finan (2006) provide evidence of this mechanism at work in Brazil. Starting in April 2003, the federal government in Brazil began to randomly audit municipal governments for the misappropriation of federal funds, and any other irregularity associated with a federally-sponsored project or public work. To promote transparency, the results of these audits were disseminated publicly to both the municipality and general media. The order in which municipalities were audited was determined by a lottery. Ferraz and Finan (2006) exploit the resulting random variation in whether a municipal government was audited before or after the municipal election to estimate the effect of the disclosure of local government corruption on the re-election success of incumbent mayors in municipal elections. They find that disclosure of audit results had a significant impact on the re-election rates of mayors found to be corrupt. ${ }^{6}$

Other constraints on political corruption may involve prosecution of corrupt officials and social sanctions such as editorials in newspapers. It is very likely that the outcome of these processes, such as an official's legal record, also affect citizens' voting behavior.

The ways in which these constraints are likely to affect politician behavior while in office depends on how we understand their motivations. If electoral gains alone motivate politicians' behavior and politicians commit absolutely to policies prior to the election, then in a democratic setting the incidence of political corruption in a society will reflect voters' willingness to condone such behavior, not politicians' willingness or ability to engage in corrupt behavior (Downs 1957). That is, electoral competition should cause candidates to implement the policies preferred by the median voter. If citizens oppose corrupt practices, and this is reflected in their voting decisions, then as long as voters observe politicians' activities politicians will choose not to engage in corrupt activities.

However, the Downsian assumption that candidate behavior is purely office-motivated

\footnotetext{
${ }^{6} \mathrm{~A}$ one standard deviation increase in reported corruption reduced the incumbent's likelihood of reelection by 25 percent.
} 
is both theoretically and empirically unsatisfactory. Since citizens are presumed to have policy preferences it is unclear why candidates (who are also citizens) will not. Most existing evidence suggests systematic differences in the policy preferences espoused by different parties (see, for instance, Lee, Moretti, and Butler (2004)).

An alternative view of politicians, and one in which a politician's identity (and policy preferences) matters, is provided by the citizen-candidate approach to political selection (Besley and Coate (1997) and Osborne and Slivinski (1996)). This approach assumes that candidates have no flexibility in platform selection - their policy positions reflect their personal policy preferences. That is, once elected, a candidate has no incentive to implement his announced platform of policies if it diverges from his preferred policies. The assumption is strong but has proven useful in understanding why candidate characteristics, such as party identity, ethnic identity and gender, tend to predict policy outcomes.

A growing body of evidence suggests that, as predicted by the citizen candidate model, the identity of elected representatives can help explain the subsequent choice of public policies by these representatives, and often overall economic performance. Jones and Olken (2005), for instance, exploit unexpected deaths of national leaders in office to isolate exogenous variation in leader identity. They ask whether leader identity matters and find that unexpected changes in the identity of a leader are associated with changes in growth outcomes - a one standard deviation increase in leader quality is associated with a growth change of $1.5 \%$ points per year. Similarly, Besley, Persson, and Sturm (2006) find evidence that individual governor identity is a significant determinant of a US state's economic performance. ${ }^{7}$

How a candidate's policy preferences affect her electability and subsequent performance also has implications for the likelihood of political corruption. ${ }^{8}$ If politicians differ

\footnotetext{
${ }^{7}$ Other papers that provide evidence on the importance of a politician's identity for policy outcomes include Lee, Moretti, and Butler (2004) and Levitt (1996) for the US and Pande (2003) and Chattopadhyay and Duflo (2004a) for India.

${ }^{8}$ A politician's overall quality and corruptness are often assumed to be negatively correlated. However, it remains possible that more corrupt individuals are also more effective at getting things done.
} 
in their honesty then in a Downsian model where citizens have a preference for honest politicians the least corrupt politician should be elected (since other policy preferences of the politician are irrelevant for her performance).

In contrast, in a citizen candidate model voters care about both the honesty of a politician and his/her policy preferences. Myerson (1993) shows that if voters choose candidates on the basis of candidate policy preferences then a coordination failure across voters may imply that the least corrupt candidate is not selected. Voters continue to vote for the relatively corrupt candidate as they are concerned that if they vote differently then the least preferred candidate may win. This result relies on citizens being strategic in their voting decisions. Banerjee and Pande (2006) consider the case of sincere voting by citizens, and demonstrate that with multi-dimensional preferences the least corrupt candidate may not be selected if his/her policy preferences do not match those of the majority population group. For instance, politicians belonging to historically socio-economically disadvantaged groups are likely to favor transfers to the poor but, being poor themselves, are also more likely to use office to enrich themselves (especially if politician salaries are low). If the intensity of citizens' policy preferences on dimensions such as redistribution differs across rich and poor countries then citizens' trade-off between politicians' policy preferences and corruption records is also likely to vary with economic development.

Caselli and Morelli (2004) consider a citizen candidate model of politics and analyze the factors which affect the supply of bad politicians in situations characterized by incomplete information. In our context bad politicians can be interpreted as politicians who are relatively more corrupt, and no better than honest politicians on other dimensions. They suggest two reasons why bad politicians, in general, will have greater incentives to pursue elective office. First, the opportunity cost of being in politics is likely to be lower for bad politicians (since their market wages will be lower than those of honest politicians). Second, a greater willingness to misuse their office implies that bad politicians reap higher returns from holding office.

Caselli and Morelli (2004) also demonstrate that political outcomes may be charac- 
terized by multiple equilibria - countries can find themselves stuck in bad equilibria such that honest citizens avoid public office because other honest citizens do so too. Multiple equilibria may arise if an elected representatives productivity depends on that of other elected representatives (this may be particularly important if decision-making is often done within committees). Another cause of multiplicity is the existence of ego rents, that is politicians care about how politics is perceived by citizens. Honest politicians get less ego rents, and are less likely to enter, if politics is perceived as full of crooks. Multiplicity of equilibria are also likely if politicians' after-office earnings opportunities depend on the average quality of the political class (this, of course, relies on voters' being able to observe quality. Otherwise low quality candidates will have an incentive to enter even if all other candidates are high quality).

\section{The Political Organization of Low Income coun- tries and its Consequences for Corruption}

\subsection{The Economic Environment and Politics}

An important feature of the process of development is increased industrialization and a greater reliance on markets for economic transactions. Relative to rich countries, a high fraction of the population in low income countries is rural and dependent on agriculture for its livelihood. In addition, low income countries in general, and Subsaharan Africa in particular, are characterized by high levels of ethnic diversity. ${ }^{9}$ Limited factor mobility

\footnotetext{
${ }^{9}$ The average country has five ethnic groups larger than 1 percent of the population. In roughly 70 percent of the countries a single ethnic group forms a population majority. Subsaharan Africa is the main exception to the rule (Fearon 2003). According to a commonly used ethnic diversity measure printed in the 1964 Atlas Narodov Mira (Atlas of Peoples of the World), fourteen out of the fifteen most ethnically heterogeneous societies in the world are in Africa; eight countries classified as high-income-countries by the World Bank Development Report are among the most ethnically homogeneous and no rich countries are among the top-15 most ethnically diverse countries.
} 
in poor countries implies that initial asset ownership is a significant determinant of an individual's lifetime wealth, and imperfect credit and insurance markets increase credit constraints at the individual level. In addition, a larger fraction of economic activity in these countries occurs in non-market settings through networks, particularly ethnic ones. ${ }^{10}$ Many low income countries are also post-colonial states. Using electoral data from 34 African countries between 1980-2000 Mozaffar, Scarritt, and Galaich (2003) argue that colonial institutions, and in particular the policy of divide and rule, provided the initial incentives for politicizing ethnic divisions and the rise of ethnic party competition. More generally, colonization in many countries increased the economic and political organization along ethnic lines and this is reflected in the present day political salience of ethnicity in these countries.

In this section we argue that these facts have a number of implications for the political organization of low income countries.

Politicians in low income countries are typically richer than the average citizen. Meyer (1969) provides evidence that in the two decades after Independence Indian politics was dominated by rich landowners, and Besley, Pande, and Rao (2005b) show that this is still true of rural politics in India - relative to other villagers, politicians in South Indian villages own significantly more land. Baland and Robinson (2005) show that prior to the introduction of the secret ballot in 1957 this was also true in Chile .

Other correlates of economic wealth have also been shown to be important for entry in politics and selection to political office. For Uttar Pradesh, India's most populous state, Banerjee and Pande (2006) find evidence of increased entry by politicians from wealthier backgrounds and by businessmen and contractors (they compare the backgrounds of elected politicians in 1969, 1980 and 1996). For South East Asia, as early as the 1970s, Scott noted the rise of business classes in politics. Laothamatos (1988) provides evidence

\footnotetext{
${ }^{10}$ Typically, membership of an ethnic group is usually defined by a descent rule, where members of a typical ethnic group share some but not necessarily all of a common language, religion, customs, sense of a homeland, and relatively dense social networks (Fearon 2003).
} 
that in Thailand 'business tycoons' have dominated politics ever since democratic elections became widespread in the late 1970s. Shatkin (2004) argues that, in Thailand and Philippines, the increasing entry of businessmen in local and national politics is related to increased affluence of the economy and greater state investment in sectors such as construction. ${ }^{11}$

The rise of business interests in the politics of low income countries has often been said to resemble 19th-century United States, which had a high representation of the business elite among urban mayors and aldermen (see, for instance, Dahl (1961), Kipp (1977)) and some railroad presidents directly entered politics (Crandall 1950).

The relative affluence of politicians that occurred in urban politics of the United States in the 19th century, of course, is also true of rich countries today. It is usually explained by the fact that entering and winning elections in any country requires substantial financial resources. It may also reflect the the relatively high returns to a political career. ${ }^{12}$ That said, there are important reasons why the economic organization of low income countries may increase the political advantage enjoyed by the elite in these countries.

Factor market imperfections in poor countries often translate into a relatively unequal distribution of land wherein a small fraction of the rural population controls a large share of total land. One consequence is the widespread use of wage contracts whereby the landless poor work for landowners. In environments where agricultural production

\footnotetext{
${ }^{11}$ He provides a case-study of the province Chonburi in the Eastern Seaboard in Thailand which benefitted from large-scale state investment in the late 1980s and 1990s. Between 1980 and 2000 manufacturing sector jobs grew from 31,000 to 121,000. Shatkin argues that this spurt in economic activity led to the rise of a local political boss, Somchai Khunpleum, who both dominates political activity in the Eastern Seaboard and heads a business empire which includes interests in mining, real estate, retail, hotel, ports, transportation, shipping and construction

${ }^{12}$ Daniel Diermeier and Merlo (2005), for instance, use data from United States to show that congressional experience significantly increases post-congressional wages, both in the private and public sectors. They also find that the non-pecuniary rewards from being in Congress are rather large (especially in the Senate). These rewards may be generated by the utility politicians derive from affecting policy outcomes, or from additional perks and benefits enjoyed by the members of Congress.
} 
exhibits significant variation in output, these contracts often take the form of efficiency wages (Bardhan and Udry 1999). Baland and Robinson (2005) develop a model to show that the resulting economic rents in the wage contracts may provide landowners with a source of political power over workers. In particular, when the workers receive rents employers can control the political behavior of their workers by threatening to withdraw these rents.

At the individual level, imperfect credit and insurance markets in low income countries imply that social networks, especially ethnic networks, are an important source of insurance for network members (Lucas and Stark 1985). Ferrara (2002), for instance, reports that in production cooperatives in the informal settlements of Nairobi, members who share the same ethnicity as the chairperson were 20 to 25 percentage points more likely to borrow from the group or from other members. This means that network members with greater access to resources or less volatile incomes are particularly important members of the network. Like the landlords in Baland and Robinson (2005), these individuals can potentially leverage their economic power within the network to obtain political support from other network members. So networks become a means through which political activity is organized. Again, there are similarities to the dominance of political machines in many US cities in the late 19th and early 20th century. These machines were typified by the existence of a political boss, a patronage hierarchy and vote buying. Immigrants in these cities provided political support to other members of their ethnic group in return for help in finding jobs and insurance. Scott (1969) provides evidence of the emergence of ethnicity based political networks, which look very similar to these urban political machines, in a number of newly independent low income countries. He describes this as exemplifying patron client relations where " an individual of higher socio-economic status (patron) uses his own influence and resources to provide protection or benefits, or both, for a person of lower status who, for his part, reciprocates by offering general support and assistance" (Scott 1972). On a related note Horowitz (1985) documents the rise of ethnic parties in a number of low income countries, and argues that the organization of political 
competition along ethnic lines is significantly more pronounced in low income countries. ${ }^{13}$

In addition to affecting the political entry and selection process, factor market imperfections in low income countries may also affect the scope of public policy. For instance, Banerjee (1997) suggests that high levels of poverty combined with imperfect credit markets will increase the demand for political allocation of resources. Along similar lines Johnson and Mitton (2006) suggests that the economic organization of low income countries also implies that they are more likely to use public policy to regulate economic activity, for instance by imposing capital controls. ${ }^{14}$ Limited labor mobility in low income countries may also affect the scope of public policy - free trade, for instance, may be associated with more negative distributional consequences (Topalova 2005).

A further factor which may affect the political organization of low income countries differentially is gender discrimination. Women are significantly less likely than men to enter politics in both high and low income countries. ${ }^{15}$ However, to the extent gender inequality is often greater among the poor, both within and across countries we may expect the barriers faced by women seeking access to politics to be particularly high in the rural areas of low income countries. Chattopadhyay and Duflo (2004b) examine mandated political representation for women in Indian villages, and report that women only stand for election in jurisdictions reserved for them. In section 3.3.2 we describe how such discrimination appears to have translated into lower female participation in politics.

\footnotetext{
${ }^{13}$ In the political science literature an ethnic party is typically seen as a "party that overtly represents itself to the voters as the champion of the interests of one ethnic group or a set of groups to the exclusion of another or others, and makes such a representation central to its mobilizing strategy." (Chandra 2004)

${ }^{14}$ Until the late 1970s, capital controls were widely used to restrict the free flow of finance in low income countries. This was seen as an effective way of stabilizing the economy if it had faced major financial crisis and also as a means of preventing speculative attacks.

${ }^{15}$ While measures to enforce womens access to political positions through quotas have been instituted in 81 countries, women constitute just 15.9 percent of the members of lower and upper houses of parliaments (United Nations, 2005)
} 


\subsection{Implications for opportunities for corruption}

\subsubsection{Power and Networks}

The nature of land relations, and the widespread existence of a network economy, lead to a greater inter-linkage of economic and political relations in low income countries. In such a setting a relatively corrupt politician who controls a large network of voters may be more likely to both succeed electorally and to remain in power. For US cities Menes (2001) describes the widespread misuse of political power for personal gain (both electoral and monetary) by the bosses of urban political machines. Baland and Robinson (2005) suggest that landowners in Chile misused their economic leverage over laborers to force them to vote in line with landowner interests. They examine how political outcomes in rural areas of Chile were affected by the introduction of the secret ballot. The introduction of the secret ballot, which limited the extent to which landlords could monitor the political behavior of workers, was associated with a significant reduction in the electoral support for the right-wing parties. The right-wing parties in Chile had traditionally favored the economic interests of landlords. It may also be the case that the inter-linkage of economic and political relations affords politicians greater opportunities for private gain. Goldstein and Udry (2005) describe how leaders in Ghanaian villages exploit their political power for economic purposes. In these villages land is held by the abusua, which is defined by matrilineal descent, on the authority of the paramount chief (or stool). The leadership of the matrilineage is locally-based and is responsible for allocating use rights within a village to members of the matrilineage. Land allocation is, thus, a political process that operates at the level of the local matrilineage. Goldstein and Udry (2005) shows that individuals in a position of political power enjoy more secure property rights on their land, and this translates into greater agricultural profits. They find that this is because the land of political leaders is less likely to be redistributed to meet the needs of villagers. 


\subsubsection{Ethnicity and Gender}

A number of papers suggest that ethnic diversity of low income countries is also an important predictor of corruption levels. Easterly and Levine (1997) uses cross country data to suggest that an important channel through which ethnic diversity reduces growth is increased corruption. More micro-evidence is provided by Olken (2006). He uses data from the Indonesian redistribution program to show that more ethnically fragmented villages lose more rice to corruption.

Chandra (2004)'s analysis of ethnic politics in India suggests that the scope of public policy can affect the political salience of ethnicity. She argues that patronage politics, typified by the use of affirmative action policies in favor of low castes in India, has made ethnicity relevant for the allocation of state resources. If identity-based targeting of resources is also a form of politics which are more susceptible to corruption, or to regulation as discussed below, then we may expect ethnification of politics, patronage politics and increased corruption to be positively correlated.

Banerjee and Pande (2006) identify a different channel through which greater organization of political competition along ethnic lines can increase political corruption. In a world with incomplete policy commitment, if individuals care about both the ethnic identity of a candidate and her corruption record, then increased polarization of voters' ethnic preferences can increase corruption. The reason is that more extreme ethnic candidates are more likely to succeed, and this will tend to favor parties with access to such candidates, even if they are, on average, of lower quality. Banerjee and Pande (2006) provide supportive evidence from India's most populous state, Uttar Pradesh. This state has both seen a significant rise in ethnic politics and increased political corruption, both as measured by voter perceptions of candidates and candidates criminal records.

While low income countries are characterized by relatively high levels of political competition along ethnic lines, political representation afforded to women in these countries remains low. Azfar, Knack, Lee, and Swamy (2001) and Dollar, Fisman, and Gatti (1999) provide cross-country evidence that female under-representation in politics is correlated 
with higher levels of corruption. Further evidence from India is provided by Duflo and Topalova (2004). They analyze a village-level data set from India with both objective and subjective information about womens actions as policymakers. The objective data comes from technical audits of the number and quality of public goods available in the villages, and it shows that women provide more public goods and at better quality than men do. Moreover, on average, women take significantly fewer bribes than men. In addition, villagers are 1.5 percentage points less likely to pay bribes for obtaining service or to the police when the village leader is a woman. ${ }^{16}$

\subsubsection{Public Allocation of Resources and Regulation}

A third set of reasons for extended opportunities for corruption relates to the type of public goods that are needed in low income countries. If officials' ability to extract bribes, and their amount, varies with the type of public good, then differences in the types of public goods being provided across high and low income countries may be associated with differences in the extent of corruption.

Banerjee (1997) develops a model of red tape and corruption in low income countries. He argues that welfare-minded governments in low income countries will seek to provide public goods to the most needy. They will introduce regulation to improve resource allocation to the poor, but elected officials can exploit these regulations to extract resources from the public while ensuring that they are not caught by higher authorities for resource mis-allocation. Alternatively, regulation can be designed and used as red tape, i.e. nonmonetary socially unproductive activities which may be used to ration public goods, or to extract resources from the public. Banerjee (1997) suggests that if the economic or political characteristics of low income countries lend themselves to greater regulation and

\footnotetext{
${ }^{16}$ Why women are less corrupt than men has received limited attention in the literature. As Azfar, Knack, Lee, and Swamy (2001) state, ' gender differences we observe may be attributable to socialization, or to differences in access to networks of corruption, or in knowledge of how to engage in corrupt practices, or to other factors.' It may also be the case that women tend not to work in sectors such as road contracting or business, and therefore derive less rents from politics.
} 
regulation provides opportunities for corruption then this suggests one reason for higher corruption in poor countries.

In a recent paper, Bertrand, Djankov, Hanna, and Mullainathan (2006) provide evidence of the misuse of regulation by corrupt officials. They examine corruption in the driving license process in India. To do so they follow a sample of 822 applicants through the process of obtaining a drivers license in New Delhi, India. Participants were randomly assigned to one of three groups: bonus, lesson, and comparison groups. Participants in the bonus group were offered a financial reward if they could obtain their license fast; participants in the lesson group were offered free driving lessons. They find that regulations associated with obtaining a driving license are exploited for rent-seeking - members of the bonus group obtained a driving license $40 \%$ faster and at a $20 \%$ higher rate. They also provide evidence that the driving test is used not to screen unsafe from safe drivers, but rather that, irrespective of their ability to drive, officials arbitrarily fail drivers at a high rate. To overcome this, individuals pay informal agents to bribe the bureaucrat and avoid taking the exam altogether. Their results suggest that bureaucrats raise red tape to extract bribes and that this corruption undermines the very purpose of regulation.

In a related empirical study Hunt (2006) uses cross-country and Peruvian data to document the fact that for individuals in low income countries with limited access to insurance, negative income or health shocks, increase an individual's demand for public services and her propensity to bribe certain officials in order to use them, possibly because victims are desperate, vulnerable, or demanding services particularly prone to corruption.

High returns to political connections and strong incentives for businessmen to enter politics in low income countries may also be a consequence of the possibility of misuse of regulations.

Such returns are not limited to poor countries - Jayachandran (2006), for instance, exploits the unanticipated resignation of Senator Jeffords from the Republican party in the US to identify corporate returns to political connections and Faccio (2006) uses data from 47 countries to show that corporate political connections are relatively widespread 
- there is at least one connected firm in 35 of the 47 countries she considers. However, the presumption in the literature seems to be that the level of corruption associated with political connections is higher in low income countries. Faccio (2006) for instance shows a strong correlation between subjective measures of corruption and the extent of political connections in the country.

Again, this may be explained by the fact that poor countries tend to be more regulated, and more regulations raises the returns to exploiting these connections for economic gain. That is, if, on average, exploiting economic regulations in low income countries provides greater rents for, say, businessmen then, relative to their counterparts in richer countries, these individuals may be more likely to enter politics. Another possibility is that the cost of using political connections in a highly networked economy may be relatively low.

Some evidence in support of this view comes from Gehlbach and Sonin (2004). They argue that the economic organization of low income and transition economies can both explain the increased entry into politics by those with business interests and the extent of political corruption. Specifically, they interpret the entry of economic elites, such as businessmen, for political office as an alternative to lobbying for influence. They illustrate their argument by the experience of a recent gubernatorial election in a large Siberian region dominated by two industrial interests, with the winner of the election the former general director of one of the two firms. This, they argue, exemplifies a more general trend in Russian politics. It is also likely that the entry of such individuals to be accompanied by a mis-allocation of resources in favor of politician owned firms.

Johnson and Mitton (2006) examine the use of capital controls by Malaysian politicians to support the financing of particular firms. They label as 'connected' firms whose officers or major shareholders have close relationships with key government officials (primarily Mahathir, Daim, and Anwar). If political connections, combined with capital controls, are a source of corruption then politically connected individuals and firms should suffer more when a macroeconomic shock reduces the government's ability to provide privileges and subsidies, and benefit more when the imposition of capital controls allows a higher level of 
priviliges. Johnson and Mitton (2006) show that after capital controls were reimposed in Malaysia in September 1998, of the estimated five billion dollar gain in market value for firms connected to Prime Minister Mahathir, about $32 \%$ can be attributed to the increase in the value of their connections

In addition to Johnson and Mitton (2006), a number of other recent papers suggest significant returns to political connections in developing countries. Khwaja and Mian (2005), for instance, estimate that in Pakistan politically connected firms borrow 45 percent more and have 50 percent higher default rates. They estimate the economy wide annual costs of the rents identified as 0.3-1.9 percent of GDP. Fisman (2001) concludes that in Indonesia a sizeable percentage of the value of well-connected firms comes from political connections. He compares returns across firms with differing degrees of political exposure at the time of rumors of the Indonesian President Suharto's worsening health. Around that time, stock prices of firms closely connected with Suharto dropped more than the prices of less well connected firms, and the stock price reactions were more severe when the news was more negative.

\subsubsection{Information}

Another source of market incompleteness which is likely to contribute to corruption is insufficient information. If individuals in low income countries are less likely to have access to the media or other sources of information about politician quality/performance, or are less educated, then their ability to identify and electorally punish corrupt politicians will also be more limited. A number of recent papers suggest that information problems may indeed be an important reason for the persistence of corruption.Ferraz and Finan (2006), for instance, find that electoral punishment for corruption in Brazilian municipalities is positively correlated with the extent of information provision in the municipality (on this, also see section 2). Along similar lines, Reinikka and Svensson (2004) compare the capture of public funds in schools in Uganda with and without access to newspapers before and after a large anti-corruption campaign. Schools with newspaper access received, on 
average, 13 percent more of their entitlement.

\subsection{Implications for willingness to tolerate corruption}

How does the economic, ethnic and gender identity of a citizen in low income countries affect her exposure to corruption and her willingness to tolerate it?

\subsubsection{Redistributive Preferences}

The average individual in a low income country is poorer and less educated than her counterpart in a rich country, and political economy models suggest that this should affect her demand for income redistribution (see, for instance, Meltzer and Richard (1981) and Roberts (1977)) and also for public goods. ${ }^{17}$

Unfortunately, for low income countries, there are very few micro-data based studies which examine how income and education affect redistributive preferences. ${ }^{18}$ In Table 1 we provide some suggestive evidence using data from World Values Surveys. The reported regressions rely on within-country variation in individual characteristics. In line with the existing literature, we observe that richer individuals are, on average, less likely to favor the political left or equality of incomes. In contrast, the correlation between redistributive preferences and education is insignificant. We do not observe any significant differences in redistributive preferences across rich and poor countries. However, there is a growing

\footnotetext{
${ }^{17}$ Specifically, if individual utility is increasing in income then at the aggregate level the demand for income redistribution should be increasing in the gap between the median and mean income - arguably, this gap, and therefore the demand for income redistribution, is higher in poorer countries. How the differences in the income distribution across rich and poor countries should affect the demand for public goods is, theoretically, less clear.

${ }^{18}$ Bratton and et al (2005) use data from the Afrobarometer surveys to examine support for liberalizing economic reforms (an additive index of support for policies such as user free (e.g. for schooling), market pricing for consumer goods, privatization and retrenchment of civil service jobs) and find that support for the reforms is increasing in income for every survey country, and in a regression on the full sample, it increases with both education and income.
} 
literature in development economics that examines how the demand for public goods varies with economic development. Foster and Rosenzweig (1996), for instance, use the green revolution in India as a partially exogenous source of increase in returns to education to estimate how expected growth and higher returns to schooling affects the demand for education. Compared to average growth areas, the enrollment rates of children of farmers in areas with yield growth rates one standard deviation above the mean are 16 percentage points higher. ${ }^{19}$ In addition, Foster and Rosenzweig (2004b) find this translated into increased provision of schools, suggesting that the demand for some public goods (such as school infrastructure) is potentially increasing in income.

Another way of examining how individual wealth affects political preferences is by studying the correlation between the population shares of different economic groups and public good outcomes. Land ownership is a good proxy for household wealth in the rural areas of low income countries. Foster and Rosenzweig (2004a) exploit time-series variation in the introduction of local elected governments across Indian states and show that the allocation of public goods across villages varied with the population shares of landed and landless households.

Another dimension of individual identity which may be important in shaping redistributive and public good preferences is ethnicity. A number of recent papers suggest that there is a greater tendency for the demand for public goods in low income countries to be organized along ethnic lines, either because ethnicity defines which groups are historically disadvantaged or because individuals of the same ethnicity tend to live in the same areas. Geographic proximity would be important if preferences for public goods may vary geographically, or if it is easier to organize public action among individuals who live nearby. It is also the case that infrastructure investments are place-specific. Bates (1974) has, in the context of Africa, stressed the role of geography in making ethnic identity an

\footnotetext{
${ }^{19}$ Foster and Rosenzweig (2004b) find that increased schooling attainment does not improve the productivity of workers engaged exclusively in menial tasks. Increases in schooling among landed households goes hand in hand with reduced schooling in landless households. The authors interpret this as suggestive of substitution of child labor from landless households.
} 
important predictor of observed public good preferences. He argues that the geographic clustering of members of an ethnic group causes the struggle for access to at least some goods to be organized on an ethnic basis. A different channel is suggested by Pande (2003). She suggests that voters belonging to minority ethnic groups will favor targeting on ethnic lines over more general income redistribution as they receive a higher per capita transfer in the former case.

A few recent papers seek to provide direct evidence on the extent of ethnic preferences, i.e. individuals' attributing positive utility to the well being of members of their own group, and negative utility to that of members of other groups. Miguel (2004) studies neighboring areas along the Tanzanian-Kenyan border and argues that processes of political socialization affects the salience of ethnic identity. Western areas of Kenya and Tanzania were similar along key dimensions in the 1960s. However, after independence Tanzania adopted arguably the most serious nation-building program in sub-Saharan Africa. This, he argues, has implied a much more limited role for ethnicity in predicting preferences in Tanzania than in Kenya.

James Habyarimana and Weinstein (2006) approach this question in a different way. They run a series of experimental games in order to examine the importance of ethnicity in shaping preferences. Their sample consists of 300 subjects from adjacent neighborhoods in Kampala, Uganda that combined high levels of ethnic diversity with low levels of public goods provision. They do not find any evidence in favor of preference-based explanations - the games suggest that co-ethnics are not more altruistic toward one another nor do they have different preferences over outcomes. They do, however, find evidence that social sanctions are easier to impose on members of one's own ethnic group.

Another set of papers show that the ethnic identity of leaders predicts policy outcomes, and interpret this as evidence of ethnic policy preferences. Pande (2003), for instance, exploits variation over time and across states in the incidence of mandated political representation for lower castes and tribal groups in India to isolate the effect of a legislator's identity on public policy. She finds that the extent to which state resources are targeted 
towards lower caste and tribal groups is increasing in the share of low caste legislators in the state assembly. Besley, Pande, and Rao (2004) examine within village allocation of resources, and find that low caste villagers are more likely to receive transfers from the state when the village leader belongs to their caste.

Another important predictor of political behavior is gender. A number of studies suggest that men and women have different preferences - compared to income or assets in the hands of men, income or assets in the hands of women raises spending on education, health, nutrition and other expenditures benefiting women and children (Lundberg, Pollak, and Wales 1997, Thomas 1997 and Duflo 2003). Increasing women's income also leads to higher survival rates for children and larger improvements in child health (Thomas 1990, 1997).

Studies, mainly based on the data for rich countries, suggest significant gender differences in policy preferences with women more likely to support liberal policies, in particular spending on child care and other child related expenses (Lott and Kenny (1999)and Edlund and Pande (2002)). There is also evidence of a strong time trend in women's political preferences in rich countries. Relative to men, women in these countries have become significantly more left-wing over the last three decades. Edlund and Pande (2002) and Edlund, Haider, and Pande (2005) interpret the growth of the political gender gap as reflecting an increasing divergence in men and women's economic well-being, and trace this divergence to the rise in non-marriage. ${ }^{20}$ This trend, however, seems to be largely absent in low income countries. One explanation for this may be that the smaller decline in marriage in low income countries. Other explanations would include greater religiosity, and the fact that lower female labor force participation rates implies that women are less exposed to labor market institutions such as unions which often espouse the cause of increased redistribution.

\footnotetext{
${ }^{20}$ Specifically, if men and women only share resources within marriage and men, on average, earn more than women then increasing non-marriage would be associated with the emergence of a political gender gap.
} 
In a world with incomplete policy commitment differences in the policy preferences of citizens (of the kind outlined above) will translate into differences in the identity of the politicians they prefer (on this, see section 2). Specifically, it will affect how citizens tradeoff a politician's corruption record versus her ability to implement the policy preferences of different ethnic groups (Banerjee and Pande 2006). This suggests one way in which an individual's redistributive preferences may affect the extent of corruption. The existence of such a channel would, for instance, provide an explicitly political underpinning to the observed negative correlation between ethnic diversity and public good outcomes. For the United States, Alesina, Baqir, and Easterly (1999) show that in more fragmented cities the provision of productive public goods (roads, hospitals, schools etc.) is lower while the types of expenditures that more closely resembles transfers targeted to ethnic and racial groups are larger. Miguel and Gugerty (2004)) exploit historic differences in geographic location of different ethnic groups to show that increased ethnic diversity in a region of Kenya reduced school funding.

It could also explain the fact that political competition is often organized on ethnic lines. Competition along ethnic lines would be accentuated if ethnic coalitions are more stable than coalitions formed along other dimensions, such as class (Esteban and Ray 2006).

\subsubsection{Participation}

Another important aspect is political participation. The extent of political participation in a country directly affects its citizens' ability to use the electoral process to punish politician misbehavior. A commonly used measure of citizen participation in politics is voter turnout - i.e. the fraction of eligible voters who show up to vote. The recent literature on social capital has also emphasized participation in civic and political associations. ${ }^{21}$

There is evidence that since the 1950s turnout has fallen in some rich countries - the

\footnotetext{
${ }^{21} \mathrm{~A}$ common definition of social capital is "the collective value of all 'social networks' and the inclinations that arise from these networks to do things for each other" (Putnam 1993)
} 
extent of this decline varies from slight in some Western European countries to significant in the United States (for evidence on the decline of voter turnout see Miller and Shanks (1996) for the US and Topf (1995) for Europe.). Putnam (2000) provides evidence of a similar decline in civic mobilization in America since the 1960s and 1970s. This includes declines in attendance at political rallies or speeches, party work and membership in civic organizations. However, Topf (1995) finds that forms of political activism other than voting have increased in Western Europe over the same time period. However, the implications of this decline for the quality of governance remains understudied.

In low income countries, political participation does not appear to have fallen over time. According to Norris (2002) electoral participation in developing countries has steadily increased during the last fifty years, a pattern most evident in Latin America (see IDEA (1997) and E.Ochoa (1987)). This pattern holds for both the newer democracies that emerged from the early 1970s onwards, as well as elections held by semi-democracies and by non-democratic regimes. ${ }^{22}$

One possible explanation for the difference in participation trends across rich and poor countries relates to differences in the costs and private benefits of participation. ${ }^{23}$ It may also be the case that the cost of corrupting the electoral process by, for instance, buying votes varies with economic development. Below we examine the evidence on how individual characteristics, which are likely to affect the costs and benefits of participation, affect political participation across rich and poor countries and discuss its implications for the incidence of corruption in these countries.

In some rich countries, especially the United States, income and education are positive predictors of turnout - though the correlation appears weak for many Western European

\footnotetext{
${ }^{22}$ This evidence is often cited as consistent with modernization theories which argue that the process of economic development induces greater political participation Norris (2002).

${ }^{23}$ The Calculus of Voting model suggests that in a two candidate election an individual will vote if $p B+d \geq c$ where $p$ is the probability that the individuals vote will swing the election; $B$ is the individuals benefit from his preferred candidate winning; $d$ is the individuals benefit from doing his civic duty; and $c$ is the cost of voting.
} 
countries. Income and education are similarly related to other forms of participation, e.g., volunteering in campaigns, contacting officials, demonstrating/protesting, working with others to solve community problems and attending meetings of a board/organizations regularly (Verba, Scholzman, and Brady (1995) discuss these findings for the United States and Blais (2000) for nine middle income countries). ${ }^{24}$ Verba, Scholzman, and Brady (1995) embed income and education in a more general model of resources, engagement and political mobilization. They emphasize the importance of having time, money, and the civic skills to participate, and note that, for example, those more likely to acquire civic skills in their workplace are those with higher income and education.

A basic problem with a causal interpretation of these findings remains the fact that a higher income is likely to be correlated with other determinants of political participation. These potentially range from better access to polling booths in richer neighborhoods to greater exposure to political news via the media. Causal interpretations of the correlation between education and propensity to vote face similar problems. To address this problem Milligan, Moretti, and Oreopoulos (2004) use compulsory schooling laws to get exogenous variation in education levels across subsequent cohorts. They find a strong and robust impact of education on participation in US, but not in UK. In a similar vein Dee (2004) uses proximity to 2-year colleges and child labor laws as instruments, and find that education increases probability of voting as well as civic engagement in the US.

Unfortunately, studies which are able to disentangle the causal impact of income and education on participation are absent for low income countries. That said, a number of papers do identify the correlation between individual income and education and political participation. A common finding in this literature is an insignificant correlation of the decision to vote or participate in political events with either education or income. Norris (2002), for instance, looks at data from twenty two countries and finds that income and education are only significant in roughly half the sample of countries. These are mainly

\footnotetext{
${ }^{24}$ He uses the Comparative Study of Electoral Systems Survey which includes survey data from nine countries (Australia, Britain, Czech Rep, Israel, Poland, Romania, Spain, Taiwan, US) in 1996-97.
} 
the richer countries. Most micro-studies also find mixed or no evidence in favor of income and education increasing participation in low income countries. Kuenzi and Lambright (2005) use individual-level attitudinal survey data for 10 sub-Saharan countries and find no significant correlation of voting with education or income. Bratton and Logan (2006) consider participation in Zambian data and find insignificant correlations of education with most measures of political participation. Krishna (2002) examines political participation by Indian villagers and finds no effect of wealth on participation, though education positively predicts participation. In Table 2 we provide some evidence using data from World Values Surveys. We estimate individual level regressions where we include country fixed effects. The results suggest that the positive correlation between education and participation is more muted in low income countries.

One possible explanation is if the cost associated with voting (mainly measured as the opportunity cost of time) is increasing in income and education at a relatively high rate in low income countries. The absence of evidence on the relative costs of voting in rich and poor countries (and how that changes along the income distribution), however, limits our ability to judge the worth of this theory.

Another explanation relates to differences in the benefits from voting for poor and less educated individuals in rich and poor countries. Social safety nets in developing countries are far smaller than in developed economies. According to Chetty and Looney (2006) in 1996, the average expenditure on social insurance as a fraction of GDP in countries with below-median per capita income was 6.8 percent while the corresponding figure in abovemedian countries was 18.5 percent. In the absence of institutionalized social safety nets the form and extent of redistribution available to individuals is much more likely to vary with changes in the elected government. This provides one argument for why the benefits of political participation may be higher for the poor and less educated in low income countries. Some supportive evidence is offered by Besley, Pande, and Rao (2005a). They examine participation in village meetings in South India and find that members of socially and economically disadvantaged groups, specifically landless and low caste individuals, are 
both more likely to attend these meetings and be chosen as beneficiaries in villages which have village meetings.

While increased political participation by voters is likely to enhance the electoral punishment for engaging in corrupt behavior, the impact of changes in the mix of who participates is less clear. One may be concerned that the poor and less educated are less able to report corrupt behavior to higher authorities and punish politicians. On the other hand, if they are the main beneficiaries of government programs then they may be better informed of illegal activities undertaken by politicians.

A different approach to identifying the link between voter identity and participation is taken by Banerjee and Iyer (2005) (on this, also see the chapter by Banerjee et al). They show that public good provision is more limited in areas which under colonial rule were exposed to political structures that created antagonistic classes (landowners and landless). They interpret this as being related to more limited collective action in these areas, and provide suggestive evidence that crime rates in these areas are higher. To the extent citizens ability to punish corrupt behavior is more limited in situations where participation rates are low, this suggests one channel through which colonial institutions may affect current political outcomes, and the extent of corruption.

Ethnic diversity may also affect the extent of political participation by different groups. ${ }^{25}$ For low income countries the existing evidence suggests that increased ethnic diversity lowers participation in community projects and therefore public good provision (see the chapter by Banerjee et al for further discussion of these issues). For instance, Okten

\footnotetext{
${ }^{25}$ For high-income countries, most studies are unable to disentangle whether ethnicity (usually defined as race), over and above socio-economic status, has an independent effect on participation. Verba and Nie (1972), for instance, find that controlling for socio-economic status, blacks in the United States participate as much, maybe more than anglo-whites. There is, however, some recent evidence that ethnic group size affects participation by members of the ethnic group. Oberholzer-Gee and Waldfogel (2005) use data from the 1994, 1996, 1998 Current Population Surveys and find that for blacks the probability of voting is increasing in the size of their district's black population. They argue that much of this is due to increased group targeting by the media when group size is large.
} 
and Osili (2004) use household data from Indonesia and finds that ethnic diversity has a negative, significant effect on monetary giving. In addition, the share of ethnic group in community has an insignificant effect on financial contributions by an individual but a positive and significant impact on time contributions. Similarly, for Pakistan Khwaja (2004) finds that 'social' heterogeneity, measured as the fragmentation into different clans, political and religious groups, is negatively associated with project maintenance. Sokoloff and Engerman (2003) explicitly examine political participation by members of different social groups in South Indian villages. They find that members of historically disadvantaged lower castes show relatively high levels of political participation. They interpret this as reflecting the fact that, due to affirmative action, members of these groups are the intended beneficiaries of many public programs

Differential levels of political participation across or within ethnic groups suggests another explanation for the observed positive correlation between ethnic diversity and political corruption. Miguel and Gugerty (2004) suggest that members of a group may be better able to impose social sanctions against members of their own ethnic group and therefore increased ethnic diversity may worsen voters' collective ability to monitor elected officials.

Most low income countries implemented universal franchise at the end of colonization, or when democratic elections were instituted, and the set of countries which explicitly restrict women's voting rights is relatively small. ${ }^{26}$ However, most studies report a significant gender gap for low income countries with women less likely to participate. Using general indices of participation constructed from survey data for fifteen African countries ?) shows that women are less likely to participate than men, even after controlling for multiple individual characteristics. Similar findings are reported by Bratton (1999) for Zambia and Krishna (2002) for India.

In Table 2, where we use data from World Values surveys, we observe significant

\footnotetext{
${ }^{26}$ As of 2005, this set included Saudi Arabia and United Arab Emirates. In Lebanon women have partial suffrage and in Bhutan each household has a single vote.
} 
gender differences in participation across countries and some weak evidence that these gender differences are accentuated in poorer countries.

A first explanation for lower female participation in low income countries is discrimination. Women may be explicitly prevented from participating, or not listened to at public forums, leading them to reduce their participation. Some evidence on this issue comes from Duflo and Topolova (2004). Since 1993, one-third of the seats and presidencies of the rural village councils in India have been reserved for women. Duflo and Topolova (2004) analyze a data set with both objective and subjective information about the womens actions as policymakers. Technical audits of the number and quality of public goods available in the villages show that women provide more public goods and at better quality than men do. However, villagers are less satisfied with the performance of female presidents in providing all services. Overall, villagers are two percentage points less satisfied with public goods when the president is a woman. They interpret this as evidence that there is a significant cultural barrier to recognizing women as competent policy makers.

In related work Beaman, Duflo, Pande, and Topolova (2006) find that female attendance and participation in village meetings is relatively higher when the village chief is a woman. Women are significantly more likely to ask a question or raise an issue at a village meeting (by 13 percentage points) when the chief is a woman. On the other hand, if a woman speaks on an issue during a village meeting conducted by a male leader she is significantly more likely to get a negative response. This gender difference in type of response is absent in the village meeting, she is much more likely to receive a bad response from the Panchayat than a man raising the same issue. A woman speaking during the meeting is 14 percentage points more likely to receive a negative response on average. In unreserved villages, this likelihood increases to 25 percentage points. However, in villages reserved for a woman, men and women seem to be treated equally when they raise issues in front of the general assembly. Finally, women may participate at lower rates if they benefit less from public transfers. This would be true if, for instance, public transfers are 
targeted at households and typically collected by the husband.. ${ }^{27}$

To the extent men were more likely to condone (and potentially exhibit) corrupt behavior (Azfar, Knack, Lee, and Swamy 2001), one cost of lower female participation is in terms of political corruption.

\subsubsection{Monitoring}

An individual's income and educational attainment might also affect her ability to monitor/punish those who are corrupt. One may argue that the relatively rich and educated are better able to punish politicians by, for instance going to court, and therefore should pay fewer bribes. In addition, the rich may be less dependent on public services and so should be better placed to avoid interactions with corrupt individuals. On the other hand, if individuals engaged in corrupt practices undertake price discrimination then the rich should, on average, pay higher bribes. Finally, if corruption is rife in business activities which are regulated (rather than in public service delivery) then the rich and more educated may actually be more exposed to corruption.

The empirical evidence on how income and education are correlated with corruption is mixed. Hunt and Lazslo (2006) use data from Uganda and Peru to find that bribery for public services works like a flat tax i.e. its incidence doesn't change across the income distribution. In contrast, a recent study of Ugandan firms suggests that corrupt officials are more likely to engage in price discrimination and larger firms are more likely to give bribes (Svensson 2003). Olken (2006) finds relatively weak evidence that richer areas in Indonesia have less corruption (as measured by the difference between the amount of rice received by different Indonesian regions to the amount intended for distribution).

Besley, Pande, and Rao (2005b) provide evidence that increased education among the voter population reduces the extent of political corruption. The main mechanism appears to be improved monitoring of elected officials, both at village meetings and via greater

\footnotetext{
${ }^{27}$ It would be interesting to check whether women remain as disaffected from politics when they are the direct beneficiaries of the public distribution system.
} 
access to the media.

\section{Conclusion}

In this chapter we have argued that differences in the economic environment faced by citizens in rich and poor countries can suggest important reasons why corruption is often higher in poor countries. Interventions which address some of the market imperfections which encourage corruption might pay rich dividends in terms of reduced corruption. These could include improving the information available to citizens through, for instance, voter awareness campaigns and breaking down existing power structures which discriminate against certain population groups (for instance, by introducing mandated political reservation for women). In addition, improving formal returns from politics and limiting the political role of ethnic parties are potential candidates for anti-corruption policies.

Overall, the evidence presented in this paper suggests that investment in specific mechanisms which alter individual incentives to engage in corrupt practices may succeed in reducing levels of corruption (One such mechanism which has received some attention in the literature is auditing - see Olken (2005)). This would suggest that the policy emphasis should be on identifying features of the economic environment which increase the incidence of corruption, not simply identifying individuals who are corrupt.

\section{Data Appendix}

The World Value regressions use data from the "World Values Survey and European Values Surveys, 1990-1993, and 1995-1997" (ICPSR 2790). Adults aged 18 and over were sampled from more than fifty countries. The surveys focus on the values and beliefs of those surveyed and contain much individual demographic information. Approximately 1,500 people were surveyed in each country in each wave of the survey, although the exact numbers vary from country to country. 
We interact our explanatory variables by a low income dummy. This dummy equals one if the county is lower income or lower middle income as classified by the World Bank's 2004 World Development Indicators. All other variables are defined in the Tables. 


\section{References}

Acemoglu, D., S. Johnson, and J. A. Robinson (2005). Institutions as the Fundamental Cause of Long-Run Growth. Handbook of Economic Growth.

Alesina, A., R. Baqir, and W. Easterly (1999). Public goods and ethnic divisions. Quarterly Journal of Economics 114(4), 1243-1284.

Azfar, O., S. Knack, Y. Lee, and A. Swamy (2001). Gender and corruption. Journal of Development Economics 64, 25-55.

Baland, J. M. and J. Robinson (2005). Land and power. mimeo.

Banerjee, A. and L. Iyer (2005). History, institutions and economic performance: The legacy of colonial land tenure systems in india. American Economic Review.

Banerjee, A. and R. Pande (2006). Parochial politics: Ethnic preferences and politician corruption. mimeo.

Banerjee, A. V. (1997). A theory of misgovernance. Quarterly Journal of Economics 112(4), 1289-1332.

Bardhan, P. and C. Udry (1999). Development Microeconomics. Oxford: Oxford University Press.

Barr, A. and D. Serra (2006). Culture and corruption. mimeo.

Bates, R. (1974). Ethnic competition and modernization in contemporary africa. Comparative Political Studies.

Beaman, L., E. Duflo, R. Pande, and P. Topolova (2006). Women policy-makers, child outcomes and gender bias in indian villages. Background Paper, State of World's Children Report UNICEF.

Bertrand, M., S. Djankov, R. Hanna, and S. Mullainathan (2006). Does corruption produce unsafe drivers? NBER working paper series ; no. w12274. 
Besley, T. and S. Coate (1997). An economic model of representative democracy. Quarterly Journal of Economics 112(1), 85-114.

Besley, T., R. Pande, and V. Rao (2004). The politics of public good provision: Evidence from indian local governments. Journal of European Economic Association 2(2-3), $416-426$.

Besley, T., R. Pande, and V. Rao (2005a). Participatory democracy in action: Survey evidence from india. Journal of European Economic Association April-May.

Besley, T., R. Pande, and V. Rao (2005b). Political selection and the quality of government: Evidence from south india.

Besley, T., T. Persson, and D. Sturm (2006). Political competition and economic performance: Theory and evidence from the united states. NBER Working Paper No. 11484 .

Besley, T. and A. Prat (2006). Handcuffs for the grabbing hand? the role of the media in political accountability. American Economic Review.

Blais, A. (2000). To Vote or Not to Vote: The Merits and Limits of Rational Choice Theory. Pittsburgh: University of Pittsburgh Press.

Bratton and et al (2005). Public opinion, democracy, and market reform in africa. mimeo.

Bratton, M. (1999). Political participation in a new democracy: Institutional considerations from zambia. Comparative Political Studies 32(5), 549-588.

Bratton, M. and C. Logan (2006). The political gender gap in africa: Similar attitudes, different behaviors.

Caselli, F. and M. Morelli (2004). Bad politicians. Journal of Public Economics.

Chandra, K. (2004). Why ethnic parties succeed. Patronage and Ethnic Head Counts in India. Cambridge: Cambridge University Press. 
Chattopadhyay, R. and E. Duflo (2004a). Women as policy-makers: Evidence from an india-wide randomized experiment. Econometrica 72(5), 1409-1443.

Chattopadhyay, R. and E. Duflo (2004b, September). Women's leadership and policy decisions: Evidence from a nationwide randomized experiment in India. 72(5), $1409-1443$.

Chetty, R. and A. Looney (2006). Income Risk and the Benefits of Social Insurance: Evidence from Indonesia and the United States. Fiscal Policy and Management: East Asia Seminar on Economics. Chicago: University of Chicago Press.

Crandall, R. (1950). American railroad presidents in the 1870s: Their background and careers. Explorations in Entrepreneurial History 2, 282-296.

Dahl, R. (1961). Who Governs? Democracy and Power in an American City. New Haven: Yale University Press.

Daniel Diermeier, M. K. and A. Merlo (2005). A political economy model of congressional careers. American Economic Review.

Dee, T. (2004). Are there civic returns to education? Journal of Public Economics 88, $1697-1720$.

Dollar, D., R. Fisman, and R. Gatti (1999). Are women really the fairer sex? corruption and women in government. Journal of Economic Behavior and Organization.

Downs, A. (1957). An economic theory of democracy. New York: Harper Collins.

Duflo, E. and P. Topalova (2004). Unappreciated service: Female politicians in india. mimeo, MIT.

Duflo, E. and P. Topolova (2004). Unappreciated service: Performance, perceptions, and women leaders in india. mimeo, MIT.

Easterly, W. and R. Levine (1997). Africa's growth tragedy: Policies and ethnic divisions. Quarterly Journal of Economics 112(4), 1203-1250. 
Edlund, L., L. Haider, and R. Pande (2005). Unmarried parenthood and redistributive politics. Journal of European Economic Association 3(1), 95-119.

Edlund, L. and R. Pande (2002). Why have women become left-wing? the political gender gap and the decline in marriage. Quarterly Journal of Economics 117(3), 917-961.

E.Ochoa (1987). The rapid expansion of voter participation in Latin America: Presidential elections 1845-1986. Statistical Abstract of Latin America, Vol 25. UCLA Latin American Center Publication: Stanford University Press.

Esteban, J. and D. Ray (2006). On the salience of ethnic conflict. mimeo.

Faccio, M. (2006). Politically connected firms. American Economic Review 96(1), 369386.

Fearon, J. (2003). Ethnic and cultural diversity by country. Journal of Economic Growth, 195-222.

Ferrara, E. L. (2002). Self-help groups and income generation in the informal settlements of nairobi. Journal of African Economies.

Ferraz, C. and F. Finan (2006). Exposing corrupt politicians: The effect of brazil's publicly released audits on electoral outcomes. mimeo, UC Berkeley.

Fisman, R. (2001). Estimating the value of political connections. American Economic Review 91(4), 1095-1102.

Fisman, R. and E. Miguel (2006). Cultures of corruption: Evidence from diplomatic parking tickets. mimeo.

Foster, A. and M. Rosenzweig (1996). Technical change and human capital returns and investments: Evidence from the green revolution. American Economic Review 86(4), 931-953.

Foster, A. and M. Rosenzweig (2004a). Democratization, decentralization and the distribution of local public goods in a poor rural economy. mimeo. 
Foster, A. and M. Rosenzweig (2004b). Technological change and the distribution of schooling: Evidence from green-revolution india. Journal of Development Economics $74(1), 87-111$.

Gehlbach, S. and K. Sonin (2004). Businessman candidates: Special-interest politics in weakly institutionalized environments.

Goldstein, M. and C. Udry (2005). The profits of power: Land rights and agricultural investment in ghana.

Horowitz, D. L. (1985). Ethnic Groups in Conflict. Berkeley: University of California Press.

Hunt, J. (2006). How corruption hits people when they are down. NBER.

Hunt, J. and S. Lazslo (2006). Bribery : Who pays, who refuses, what are the payoffs?

IDEA (1997). Voter Turnout from 1945 to 1998: A Global Report. Stockholm:: International IDEA.

James Habyarimana, Mccartan Humphreys, D. P. and J. Weinstein (2006). Why does ethnic diversity undermine public goods provision? an experimental approach. mimeo.

Jayachandran, S. (2006). The jeffords effect. Journal of Law and Economics.

Johnson, S. and T. Mitton (2006). Cronyism and capital controls: Evidence from malaysia. mimeo, SSRN.

Jones, B. and B. Olken (2005). Do leaders matter? national leadership and economic growth since world war ii. Quarterly Journal of Economics 120 (3), 835-864.

Khwaja, A. and A. Mian (2005). Do lenders favor politically connected firms? rent provision in an emerging financial market. Quarterly Journal of Economics 120(4).

Khwaja, A. I. (2004). Can good projects succeed in bad communities? collective action in the himalayas. 
Kipp, S. M. (1977). Old notables and newcomers: The economic and political elite of greensboro, north carolina, 1880-1920. Journal of Southern History 43(3), 373394.

Krishna, A. (2002). Enhancing political participation in democracies - what is the role of social capital? Comparative Political Studies 35(4), 437-460.

Kuenzi, M. and G. Lambright (2005). Who votes in africa? an examination of electoral turnout in 10 african countries.

Laothamatos, A. (1988). Business and politics in thailand: New patterns of influence. Asian Survey.

Lee, D. S., E. Moretti, and M. Butler (2004). Do voters affect or elect policies? evidence from the u.s. house. Quarterly Journal of Economics 119(3), 807-860.

Levitt, S. (1996). How do senators vote? disentangling the role of voter preferences, party affiliation and senate ideology. American Economic Review 86(3), 425-441.

Lott, J. R. and L. W. Kenny (1999). Did women's suffrage change the size and scope of government. Journal of Political Economy CVI, 1163-1198.

Lucas, R. E. and O. Stark (1985). Motivations to remit: Evidence from botswana. Journal of Political Economy 93 (5), 901-918.

Mauro, P. (1995). Corruption and growth. Quarterly Journal of Economics 110, 681712.

Meltzer, A. H. and S. F. Richard (1981). A rational theory of the size of government. Journal of Political Economy LXXXIX, 914-927.

Menes, R. (2001). Corruption in cities: Graft and politics in american cities at the turn of the twentieth century. mimeo.

Meyer, R. (1969). The political elite in an underdeveloped society. Ph.D. Dissertation, University of Pennsylvania.

Miguel, E. (2004). Ethnic divisions, social sanctions, and public goods in kenya. World Politics. 
Miguel, E. and M. K. Gugerty (2004). Ethnic divisions, social sanctions, and public goods in kenya. Journal of Public Economics.

Miller, W. and J. M. Shanks (1996). The New American Voter. Cambridge, MA: Harvard University Press.

Milligan, K., E. Moretti, and P. Oreopoulos (2004). Does education improve citizenship? evidence from the united states and the united kingdom. Journal of Public Economics 88(9-10), 1667-1695.

Mozaffar, S., J. Scarritt, and G. Galaich (2003). Electoral institutions, ethnopolitical cleavages, and party systems in africa. American Political Science Review 97(3), 379-390.

Myerson, R. (1993). Effectiveness of electoral systems for reducing government corruption: A game theoretic analysis. Games and Economic Behavior 5, 118-132.

Norris, P. (2002). Democratic Phoenix: Reinventing Political Activism. New York: Cambridge University Press.

Oberholzer-Gee, F. and J. Waldfogel (2005). Strength in numbers: Group size and political mobilization. Journal of Law and Economics 48, 73-91.

Okten, C. and U. Osili (2004). Contributions in heterogeneous communities: Evidence from indonesia. Journal of Population Economics 14, 603-626.

Olken, B. (2006). Corruption and the costs of redistribution: Micro evidence from indonesia. Journal of Public Economics 90, 853-870.

Osborne, M. and A. Slivinski (1996). A model of political competition with citizencandidates. Quarterly Journal of Economics 111(1), 65-96.

Pande, R. (2003). Can mandated political representation provide disadvantaged minorities policy influence? theory and evidence from india. American Economic Review 93(4), 1132-1151. 
Pande, R. (2006). Why arent we achieving the millenium development goals?book review for the proceedings of annual world bank conference in development economics. Journal of Economic Literature.

Pande, R. and C. Udry (2005). Institutions and development: A view from below. mimeo.

Persson, T. and G. Tabellini (2003). The Economic Effects of Constitutions: What Do the Data Say? Cambridge: MIT Press.

Putnam, R. (1993). Making Democracy Work. Civic traditions in modern Italy. Princeton: Princeton University Press.

Putnam, R. (2000). Bowling Alone. The collapse and revival of American community. New York: Simon and Schuster.

Reinikka, R. and J. Svensson (2004). The power of information: Evidence from a newspaper campaign to reduce capture of public funds. mimeo, IIES.

Roberts, K. (1977). Voting over income tax schedules. Journal of Public Economics.

Scott, J. (1969). Corruption, machine politics and political change. American Political Science Review 63, 1142-1158.

Scott, J. C. (1972). Patron-client politics and political change in southeast asia. American Political Science Review 66.

Shatkin, G. (2004). Globalization and local leadership: Growth, power and politics in thailand's eastern seaboard. International Journal of Urban and Regional Research 28.

Sokoloff, K. and S. Engerman (2003). Institutions, factor endowments, and paths of development in the new world. Journal of Economic Perspectives 14(3), 217-232.

Svensson, J. (2003). Who must pay bribes and how much? evidence from a cross section of firms. Quarterly Journal of Economics 118, 207-230. 
Svensson, J. (2005). Eight questions about corruption. Journal of Economic Perspectives 19, 19-42.

Topalova, P. (2005). Trade liberalization, poverty, and inequality: Evidence from indian districts. NBER.

Topf, R. (1995). Beyond Electoral Participation. Citizens and the State. Oxford: Oxford University Press.

Treisman, D. (2000). The causes of corruption: A cross national study. Journal of Public Economics 76(3), 399-457.

Verba, S. and N. Nie (1972). Participation In America: Social Equality and Political Democracy. New York: Harper and Row.

Verba, S., K. L. Scholzman, and H. E. Brady (1995). Voice and Equality: Civic Voluntarism in American Politics. Cambridge, MA: Harvard University Press. 
Table 1: Interest in Government and Redistributive Preferences: World Values Survey

\begin{tabular}{|c|c|c|c|c|c|c|}
\hline & \multicolumn{3}{|c|}{ "Government Does } & \multicolumn{3}{|c|}{ Importance of } \\
\hline & Income Equality & Too Little & Left & Discuss Politics & Politics & Interest in Politics \\
\hline & $(1)$ & $(2)$ & $(3)$ & $(4)$ & $(5)$ & $(6)$ \\
\hline \multirow[t]{2}{*}{ Female } & 0.0137 & 0.0086 & $-0.0281^{\star * *}$ & $-0.0651^{\star \star *}$ & $-0.0445^{\star \star \star}$ & $-0.1197^{\star \star *}$ \\
\hline & $(0.0030)^{\star \star \star}$ & $(0.0017)^{\star \star \star}$ & $(0.0062)$ & $(0.0054)$ & $(0.0059)$ & $(0.0096)$ \\
\hline Female*Low Income & -0.0129 & -0.0108 & 0.0037 & $-0.0175^{\star}$ & $-0.0436 * \star \star$ & 0.0035 \\
\hline country & $(0.0067)^{\star}$ & $(0.0056)^{\star}$ & $(0.0092)$ & $(0.0099)$ & $(0.0121)$ & $(0.0178)$ \\
\hline \multirow[t]{2}{*}{ Income below 50th decile } & $0.0804^{\star * *}$ & 0.0039 & $0.0164^{\star * \star}$ & $-0.0275^{\star \star \star}$ & 0.0140 & $-0.0518 * \star \star$ \\
\hline & $(0.0085)$ & $(0.0053)$ & $(0.0060)$ & $(0.0052)$ & $(0.0155)$ & $(0.0103)$ \\
\hline Income below 50th decile* & -0.0147 & 0.0120 & -0.0045 & -0.0046 & -0.0244 & $0.0389 *$ \\
\hline Low income country & $(0.0212)$ & $(0.0134)$ & $(0.0081)$ & $(0.0126)$ & $(0.0206)$ & $(0.0209)$ \\
\hline \multirow[t]{2}{*}{ Primary Education or less } & 0.0263 & -0.0011 & -0.0047 & $-0.1006^{\star \star \star}$ & $-0.2120^{\star \star \star}$ & $-0.2034^{\star \star \star}$ \\
\hline & $(0.0249)$ & $(0.0344)$ & $(0.0128)$ & $(0.0159)$ & $(0.0383)$ & $(0.0395)$ \\
\hline Primary Education*Low & 0.0213 & -0.0585 & 0.0083 & $0.0465^{\star \star}$ & $0.1590^{\star \star \star}$ & 0.0843 \\
\hline Income country & $(0.0266)$ & $(0.0469)$ & $(0.0288)$ & $(0.0195)$ & $(0.0452)$ & $(0.0706)$ \\
\hline Fixed Effect & Country & Country & Country & Country & Country & Country \\
\hline $\mathrm{N}$ & 142923 & 142923 & 142923 & 142923 & 142923 & 142923 \\
\hline R-squared & 0.09 & 0.58 & 0.04 & 0.06 & 0.09 & 0.13 \\
\hline
\end{tabular}

Notes:

1.Standard errors, clustered by country, in parentheses.

2. Data are from World Values Surveys (see Data Appendix for more details). Left is a measure of political ideology on a scale from left to right, where $1=$ completely to the left, $10=$ completely to the right. We define Left as a dummy varible $=1$ if ideology is from 1 to 3 Importance of Politics: How important is politics in your life? Scale from 1 to 4 . $1=$ very important, 2 = rather important, $3=$ not very important, $4=$ not at all important. Interest in Politics: How interested would you say you are in politics? Scale from 1 to $4.1=$ very interested, 2 = somewhat interested, 3 = not very interested, $4=$ not at all interested.

3. Regressions also include age dummy and its interaction with low income, dummies for being married, divorced, separated and widowed, and year and country fixed effects.

4. * significant at $10 \%$; ** significant at $5 \%$; ** significant at $1 \%$ 
Table 2: Overall Political Participation and Involvement with Parties and Labor Unions

\begin{tabular}{|c|c|c|c|c|c|c|c|}
\hline & $\begin{array}{c}\text { Political } \\
\text { Participation }\end{array}$ & $\begin{array}{c}\text { Active Party } \\
\text { Member }\end{array}$ & $\begin{array}{c}\text { Active Labor } \\
\text { Union Member }\end{array}$ & $\begin{array}{c}\text { Sign } \\
\text { Petition }\end{array}$ & $\begin{array}{c}\text { Join } \\
\text { Boycott }\end{array}$ & $\begin{array}{c}\text { Lawful } \\
\text { Demonstrat }\end{array}$ & $\begin{array}{l}\text { Unofficial } \\
\text { Strike }\end{array}$ \\
\hline & (1) & (2) & (3) & (4) & (5) & (6) & (7) \\
\hline \multirow{2}{*}{ Income below 50th decile } & -0.0192 & -0.0087 & -0.0057 & -0.0449 & -0.0128 & -0.0193 & -0.0041 \\
\hline & $(0.0041)^{\star \star \star}$ & $(0.0022)^{\star \star \star}$ & $(0.0025)^{\star \star}$ & $(0.0075)^{\star \star \star}$ & $(0.0049)^{\star \star}$ & $(0.0055)^{\star \star \star}$ & $(0.0022)^{\star}$ \\
\hline Income below 50th decile* & 0.0073 & 0.0044 & -0.0001 & -0.0028 & 0.0114 & 0.0027 & 0.0022 \\
\hline Low income country & $(0.0076)$ & $(0.0037)$ & $(0.0053)$ & $(0.0186)$ & (0.0103) & $(0.0112)$ & $(0.0053)$ \\
\hline \multirow[t]{2}{*}{ Primary Education or less } & -0.0983 & -0.0247 & -0.0334 & -0.1390 & -0.0562 & -0.0700 & -0.0276 \\
\hline & $(0.0126)^{\star \star \star}$ & $(0.0137)^{*}$ & $(0.0083)^{\star \star \star}$ & $(0.0164)^{\star \star \star}$ & $(0.0142)^{\star \star \star}$ & $(0.0150)^{\star \star \star}$ & $(0.0123)^{\star \star}$ \\
\hline Primary Education or less*Low & 0.0470 & 0.0265 & 0.0277 & 0.0999 & 0.0290 & 0.0386 & 0.0150 \\
\hline Income country & $(0.0180)^{\star \star}$ & $(0.0168)$ & $(0.0099)^{\star \star \star}$ & $(0.0286)^{\star \star \star}$ & $(0.0184)$ & $(0.0266)$ & $(0.0110)$ \\
\hline \multirow[t]{2}{*}{ Female } & -0.0533 & -0.0174 & -0.0177 & -0.0326 & -0.0238 & -0.0651 & -0.0320 \\
\hline & $(0.0038)^{\star \star \star}$ & $(0.0022)^{\star \star \star}$ & $(0.0026)^{\star \star \star}$ & $(0.0088)^{\star \star \star}$ & $(0.0041)^{\star \star \star}$ & $(0.0064)^{\star \star \star}$ & $(0.0036)^{\star \star \star}$ \\
\hline Female*Low Income & -0.0087 & -0.0134 & 0.0042 & -0.0069 & -0.0158 & 0.0096 & 0.0033 \\
\hline $\begin{array}{l}\text { country } \\
\text { Fixed Effect }\end{array}$ & $(0.0073)$ & $(0.0053)^{\star \star}$ & (0.0050) & (0.0127) & (0.0103) & (0.0118) & $\begin{array}{l}\text { (0.0067) } \\
\text { Country }\end{array}$ \\
\hline Fixed Effect & Country & Country & Country & Country & Country & Country & Country \\
\hline $\mathrm{N}$ & 142923 & 142923 & 142923 & 142923 & 142923 & 142923 & 142923 \\
\hline R-squared & 0.15 & 0.03 & 0.03 & 0.20 & 0.04 & 0.05 & 0.03 \\
\hline
\end{tabular}

Notes:
Standard errors, clustered by country, in parentheses.

Political Participation is an index, valued between 0 and 1, weighted by answers to several questions about political participation. Active Party Member is an indicator variable $=1$ if respondent is an active member of a political party. Active Labor Union Member is an indicator variable=1 if respondent is an active member of a labor union. Sign Petition is an indicator variable $=1$ if respondent has ever signed a petition. Join Boycott is an indicator variable $=1$ if respondent has ever joined a boycott. Lawful Demonstration is an indicator variable $=1$ if respondent has ever been involved in a lawful demonstration. Unofficial Strike is an indicator variable $=1$ if respondent has ever joined an unofficial strike.

Regressions also include age dummy and its interaction with low income, dummies for being married, divorced, separated and widowed, and year and country fixed effects.

* significant at $10 \%$; ** significant at $5 \%$; *** significant at $1 \%$ 